\title{
Exploration and Reflection on the Teaching Mode of Academic English for Postgraduates in the New Situation
}

\author{
Ghamgeen Izat Rashed, Xiaoyun Guo, Weimin Guan
}

School of Electrical Engineering, Wuhan University, Wuhan, China

\section{Email address:}

ghamgeen@whu.edu.cn (G. I. Rashed)

\section{To cite this article:}

Ghamgeen Izat Rashed, Xiaoyun Guo, Weimin Guan. Exploration and Reflection on the Teaching Mode of Academic English for Postgraduates in the New Situation. Science Journal of Education. Vol. 7, No. 1, 2019, pp. 50-53. doi: 10.11648/j.sjedu.20190701.19

Received: April 29, 2019; Accepted: May 24, 2019; Published: June 15, 2019

\begin{abstract}
The teaching of postgraduate specialized English has changed from the purely professional vocabulary learning or the imparting of professional technical knowledge to the application ability of academic English. In order to adapt to this change, based on the investigation and analysis of the current situation of professional English teaching and the study characteristics of the graduate students, this paper discusses the main problems existing and builds a more efficient professional English learning class. A series of reform and exploration ideas are put forward from the aspects of strengthening professional pertinence, giving full play to students' independent learning ability and carrying out cooperative teaching.
\end{abstract}

Keywords: Academic English, Teaching Mode, Postgraduate Student

\section{Introduction}

Under the globalized environment, English has become the main way in international academic exchanges as well as the exchange of research results between non-native English scholars in the whole world. Under this international background, with the further deepening of China's reform and opening up, the international cooperation and international exchanges of the postgraduate groups are becoming more and more frequent, prompting the graduate students to possess good academic English communication and application ability to cope with the rapid development of global science and technology and the multichannel sources of information sources. Therefore it is also necessary to explore the corresponding professional English teaching mode for postgraduates. English for Academic purposes (EAP) by demonstrating how business management approaches and tools can enhance the content and performance management of in-sessional academic skills provision was presented, [1] investigation variation in the use of questions in instructional settings that differ according to communicative mode was introduced. [2] A survey of 285 engineering sophomores, [3] to gain a thorough knowledge of engineering students difficulties in English writing was undertaken, the structure and content of the English language teaching for Master's Degree and Ph.D. students at a technology university, which is based on developing skills required for special engineering and academic purposes was studied. [4] The environment CALEP-Web that integrates adaptive testing into a task-based environment in the domain of English for an Academic purpose was introduced, [5] the process of using a new approach to design online language learning materials in the context of small scale projects within Higher Education in the UK was introduced. [6] The status of English communication education and Englishmedium instruction at a Korean engineering school and to offer workable suggestions for English communication training for Korean graduate engineering students was studied. [7]

On the basis of the investigation and analysis of the current situation of English Teaching for electrical major graduate students and the study characteristics of the graduate students, this paper discusses the main problems that exist at present, and puts forward a series of reform and exploration ideas.

\section{The Difference Between Foreign Eap Teaching and Eap Teaching in China}

As a branch of ESP (English for Special Purpose), the teaching activities of academic English in foreign countries 
begin with a number of courses offered by a single teacher for professional learning to help non-native English learners. In many colleges and universities in Britain, the teaching institutions of academic English are mainly in the language centers of universities or independent language training institutions, available to foreign students who are ready to enter British universities and foreign students who have been admitted but also need to improve their professional academic English. There are three main characteristics of Academic English course in the course setting: the organic combination of the preparatory course with the synchronous tutoring course, the comprehensiveness of the course content and the diversity of the course form, the providing of the other ways of autonomous learning, distance learning and computer aided language learning besides the formal classroom teaching. [8] While the present domestic university graduate students' Academic English courses are set only in the classroom teaching with the arrangement of 28-36 hours, and not providing any synchronous guidance courses, that is, after the students have completed the academic English course, after-school tutoring continues to be provided individually so as to fill in the deficiency of the body difference that cannot be taken care of in the classroom teaching.

\section{The Different Characteristics of Undergraduate Learning English and Postgraduate Learning English in China}

It is mainly for domestic undergraduate students to learn English for credits, scholarships, CET-4 or CET-6 examinations and postgraduate exams. Some undergraduates are motivated by the purpose of further studying abroad, and they will consciously improve the ability of speaking, reading and writing, but they still face the lack of English environment, and most of them should turn to Off - campus organizations for related training. While the postgraduates focus on scientific research or academic paper writing. They do need English as a practical skill to refer to foreign related literatures, conduct academic exchanges, write and publish English research papers or abstracts. [9] Therefore, from this perspective, postgraduates' motivation to learn English is stronger.

In addition, graduate students have more autonomy and initiative than undergraduate students, so they are not interesting for the teacher centered instillation teaching. If the teachers continue to follow the traditional teaching mode of "translation + reading + writing", it is difficult to achieve the purpose of improving the application ability of postgraduate English.

\section{Analysis of the Teaching Level of English for Academic Purposes}

The teaching of professional English can be divided into basic level, core level and advanced level. At the undergraduate stage, bilingual teaching in major courses is at the basic level. Although in these courses English original textbooks are used as teaching materials, the teaching goal is mainly to teach professional knowledge, and the application of English in the study of this major is supplemented. Therefore, the emphasis of teachers and students' learning will inevitably focus on the study of professional knowledge, and the application of English skills in the academic field of the major is not deep.

The teaching of professional English at the graduate level is at the core level. The teaching at this level is mainly aimed at graduate students with good English foundation and professional basic knowledge. In addition to requiring students to use English to learn professional knowledge, we should also cultivate and improve students' ability to learn autonomously and critically.

The third level refers to help students realize the application ability of academic English with a qualitative leap. In order to achieve this level, it needs a long time of precipitation and accumulation, especially with the help of individualized guidance. However, as mentioned earlier, the academic English Teaching for domestic graduate students is short of this sector. If they do not have relevant activities to continue and strengthen the study and application of professional academic English, the skills they have learned will be forgotten after the completion of the English course. Through a survey of the graduate students of electrical specialties, it is found that there are still a number of postgraduates who publish articles in foreign periodicals or attend international conferences every year, which is related to the tutor or the overall atmosphere of the laboratory. If the tutor has a request for his students to publish English articles, or the senior students in their labs also have the experience of attending international conferences, it can replace the role of personalized counseling to a certain extent to help students achieve the advanced level of academic English. [10] At this level, the postgraduates can not only improve the academic communication and academic literacy, but also improve their cross-cultural communication, communication and cooperation, as well as the ability to participate in international competition.

\section{Innovative Curriculum Construction from Scientific English to Academic English}

The reform and development of general English teaching has greatly improved the English level of undergraduates and even graduate students, and also put forward higher requirements for the graduate students' English training. At present, the needs of academic English for graduate students in China are not only stayed in reading professional literatures, writing English abstracts, or listening to English academic reports. Many universities have asked for postgraduate students to publish academic papers in 
professional journal, deliver academic speeches and reports in international academic conferences, or to take other highly internationalized academic activities. The teaching of postgraduate courses is an important way to cultivate and improve the graduate students' scientific research and innovation ability, therefore the innovation course construction itself is the process of cultivating the creative ability of graduate students.

\subsection{Establish Quality Assurance System and Strengthen the Teaching Management of Postgraduates' Academic English}

Academic English writing course is of practical significance for postgraduates. This course provides methods and related training for Postgraduates in writing scientific papers. But the phenomenon of late for class, early retreat and even absenteeism frequently happened due to the heavy research task and short of time for the graduate student, and sometimes related to the attitude of the tutor or the surrounding students towards this course. Therefore, there must be strict discipline to ensure the good learning effect of the course. At the beginning of the class, the teacher should inform the students of the evaluation standard of the course (consisting of attendance, regular homework and final test), and give the course calendar to the students.

In addition, during the assessment of the teaching effect at the end of the course, the final test papers of the students will not only be evaluated by the teachers, but also be sent to their respective tutors, so the professional tutors will also be involved in the evaluation of the teaching effect.

\subsection{Give Full Play to the Role of Teachers' Groups and Student Bodies}

At present, the construction of professional English teaching is relatively weak compared with that of general English teaching in China. In addition, the research direction of electrical major graduate students is also divided into power system and automation, high voltage insulation technology, power electronics technology, electric power measurement technology and so on. Therefore, single teacher cannot satisfy the requirement of all postgraduates in this major. In order to make full use of teachers' advantages, professional teachers with English Specialty in various professional directions are selected to form a team of teachers of academic English courses, with a foreign teacher included. This combination takes full account of the professional needs of graduate students, and the addition of foreign teachers will also enable students to feel the atmosphere of internationalization in the classroom and improve their participation. At the same time, the teaching team will share the common direction of building the academic English course, which is helpful to achieve the coordinated development of the entire teaching team.

In order to cultivate the graduate student's international academic cooperation spirit, 4 to 5 students of the same professional direction, or even the students from the same laboratory, will make a team. In this team, students will select the high level SCI or EI papers published in their own professional field as the research objects, complete academic posters, slides, academic reports and other assignments together. After independent paper writing, each paper will be exchanged and reviewed within the team. Each member can point out the advantages and disadvantages of the other, and learn the writing skills from each other. Using this grouping method, postgraduates can also create an atmosphere of academic English learning after class and continue to relate to each other after the end of the course.

\subsection{Take the Advantage of the Network to Further Extend the Classroom Learning}

At present, the coverage rate of campus network in our country is very high, which can be fully used in classroom teaching and after-class autonomous learning. The network learning is not limited by time and space, so it is suitable for the postgraduate learning especially, and it will also make up for the lack of professional English classroom teaching hours. By browsing recommended international authoritative journals and foreign professional websites, students are exposed to the latest development or researching information in this field, which is helpful to improve students' ability to perceive new technologies and new applications, and promote their own exploration. Students are also encouraged to communicate with teachers and students at any time, hand in homework, exchange and evaluate on each other. In the process of these interactive activities, their academic English application ability has also been improved. In addition, the Moocs teaching platforms set up by foreign universities are introduced to make up for the lack of English language environment for domestic students.

\subsection{Make Full Use of the Advantages of the Industry and Improve the Practicability of Professional English}

With the implementation of the Belt and Road strategic planning, domestic enterprises turn to develop the international market and undertake foreign cooperation projects. Professional English can also turn from international academic conferences and academic paper publication to the practical technical exchanges and cooperation among engineers with different languages. The domestic power enterprises have undertaken a large number of foreign projects in South Asia and Latin America. On the one hand, it is necessary to send engineers and technicians from the country, and on the other hand, it need to train technicians selected from the local technical personnel. The institute has set up the excellent engineers training projects in many enterprises, carried out a variety of school enterprise cooperation aimed at training domestic and foreign professionals. The graduate students can actively participate in these projects and improve their professional English application ability in actual activities. 


\section{Conclusions}

Based on the present teaching situation of English for graduate students in electrical major, this paper summarizes the short comings of the current teaching mode and puts forward some relevant improvement measures, which also provides some reference for improving the international academic communication and scientific research ability of the graduate students. English learning motivation has a great effect on English learning attitude and influence. Most of the students consider the application of communicative skills as one of the goals of English learning. Therefore, one of the key methods to improve major English proficiency is to let them understand the importance of English in the electrical industry at the beginning of their course. Implementing small class sizes, improving facilities, encouraging teachers to apply new teaching methods are all essential methods. The teaching methods currently used are instruction-oriented, therefore, an interactive way to assist students, including panel discussions, dialogs in life-like scenarios, role plays and other interactive methods are most welcome.

\section{Acknowledgements}

The Author would like to present special thanks to Wuhan University for funding this research paper with a project no: 1402-413200017.

\section{References}

[1] Olwyn Alexander, Diane Sloan, kate Hughes, and tal, Engaging with quality via the CEM model: Enhancing the content and performance management of postgraduate insessional academic skills provision, Journal of English for Academic Purposes 27 (2017) 56-70.
[2] Belinda Crawford Camiciottoli, Interaction in academic lectures vs. written text materials: The case of questions, Journal of Pragmatics 40 (2008) 1216-1231.

[3] Xiao, Gensheng, English academic writing difficulties of engineering students at the tertiary level in China, 13 (3), 2015, p. 259-263.

[4] Elvira E. Valeeva, English for special and academic purposes for graduate students at technological university, 2013 International Conference on Interactive Collaborative Learning (ICL), 25-27 Sept. 2013.

[5] Goncalves, Jean P., Aluisio, Sandra M., de Oliveira, and etal, A learning environment for English for academic purposes based on adaptive tests and task-based systems, Lecture Notes in Computer Science, v 3220, 2004, p. 1-11.

[6] Jie $\mathrm{Hu}$, Exploration of a new approach for designing online English language learning materials: A case study in supporting the academic reading of international masters degree students in a British university, $20116^{\text {th }}$ International Conference on Computer Science and Education (ICCSE), 26 Sept. 2011.

[7] Eun Gyong Kim and Abigail Shin, Seeking an efective pogram to improve communication skills of non-English speaking graduate engineering students: The case of a Korean Engineering School, IEEE Transactions on professional communication, vol. 57, No. 1, March 2014.

[8] Liu, Liang Chen, Liu Juanjuan, Graduate English teaching from science and technology to academic English, overseas English, September 2014, p11-12.

[9] Wang Zhuang, Lei Lin, exploration and practice of teaching reform of professional English for science and engineering [J], Journal of higher education research, 2010 (1): 154-156.

[10] Cheng Shilu, Zhang Guoyang, ESP teaching theory and practice, foreign language teaching research, 1995 (4): 51-54. 